\title{
Wilson Disease and Hepatocellular Carcinoma
}

Key words: carcinogenesis, copper, hepatocellular carcinoma, Wilson disease

Wilson disease is an autosomal recessive disorder characterized by the progressive accumulation of copper in the body. The failure of the hepatocytes to excrete copper into bile and the decreased copper incorporation into ceruloplasmin causes the metal to accumulate in the body (1). The gene responsible for Wilson disease has been cloned and shown to encode a cation-transporting P-type ATPase (2-4). Wilson disease gene product, designated as ATP7B, functions in copper secretion into plasma coupled with ceruloplasmin synthesis and biliary copper excretion. Increased amounts of copper deposited in the tissues are responsible for the hepatic, neurological and corneal manifestations (1).

Hepatic dysfunction is the presenting feature of Wilson disease in more than half of the patients. The 3 major patterns of hepatic involvement are chronic active hepatitis, cirrhosis and fulminant hepatic failure. Hepatocellular carcinoma (HCC) is a well-recognized complication of cirrhosis with various etiologies. However, HCC has been rarely reported in patients with Wilson disease. In most of the previous studies about Wilson disease and HCC, the patients with other risk factors were not exactly excluded (5, 6). Especially, the association of $\mathrm{HBV}$ and $\mathrm{HCV}$ has not been fully analyzed. Iwadate et al reported a case of Wilson disease complicated with HCC (7).

See also p 1042.

The patient was negative for HBs antigen, $\mathrm{HCV}$ antibody or HCV-RNA in the serum. Although anti-HBs antibody and anti-HBc antibody (low titer) were positive, HBX-DNA was negative by the PCR analysis in the liver. The other HBVDNA fragment, such as $\mathrm{C}$ or $\mathrm{S}$ region, may be associated with $\mathrm{HCC}(8,9)$. Therefore, the association of HBV in the occurrence of HCC can not be completely excluded. However, the occurrence of this tumor may be associated with Wilson disease itself.

HCC is very rare in patients with Wilson disease and a protective role of copper against hepatic oncogenesis has been postulated (5). However, it is puzzling, because the LEC rat, in which a partial deletion at the $3^{\prime}$ end in $a t p 7 b$ is demonstrated, develops HCC despite an excess of copper in the liver $(10,11)$. Copper chelating agents inhibit the development of liver tumors in LEC rat (12). Therefore, the susceptibility of LEC rats to liver carcinogenesis could be explained by an excess of copper and/or iron accumulation (13). The low incidence of HCC in patients with Wilson disease may be attributable to the significantly shortened life expectancy in untreated patients that does not allow time for carcinoma to develop (14). Hepatocyte proliferation accompanied by liver cell damage is essential for liver tumor development (15). The patient reported by Iwadate et al (7) had received $400 \mathrm{mg} /$ day of D-penicillamine for 6 years. This dose of D-penicillamine is insufficient for adult males. Insufficient chelating therapy may slightly reduce body copper content but induce prolonged hepatocyte injury. Thus, repeated death and regeneration of hepatocytes may contribute to hepatic oncogenesis even in a high copper environment. Cirrhotic patients with Wilson disease, especially patients with an accompanying elevated serum alanine aminotransferase level, should be regularly screened for hepatocellular carcinoma.

Masaru HARADA, MD, PhD, FJSIM Second Department of Medicine and Research Center for Innovative Cancer Therapy of the 21st Century COE Program for Medical Science, Kurume University School of Medicine, Kurume 830-0011

\section{References}

1) Linder MC, Hazegh-Azam M. Copper biochemistry and molecular biology. Am J Clin Nutr 63: 797S-811S, 1996.

2) Bull PC, Thomas GR, Rommens JM, Forbes JR, Cox DW. The Wilson disease gene is a putative copper transporting P-type ATPase similar to the Menkes gene. Nat Genet 5: 327-337, 1993.

3) Petrukhin K, Fischer SG, Pirastu M, et al. Mapping, cloning and genetic characterization of the region containing the Wilson disease gene. Nat Genet 5: 338-343, 1993.

4) Tanzi RE, Petrukhin K, Chernov I, et al. The Wilson disease gene is a copper transporting ATPase with homology to the Menkes disease gene. Nat Genet 5: 344-350, 1993.

5) Cheng WS, Govindarajan S, Redeker AG. Hepatocellular carcinoma in a case of Wilson's disease. Liver 12: 42-45, 1992.

6) Polio J, Enriquez RE, Chow A, Wood WM, Atterbury CE. Hepatocellular carcinoma in Wilson's disease. Case report and review of the literature. J Clin Gastroenterol 11: 220-224, 1989.

7) Iwadate H, Ohira H, Suzuki T, et al. Hepatocellular carcinoma associated with Wilson's disease. Intern Med 43: 1042-1045, 2004.

8) Yotsuyanagi H, Shintani Y, Moriya K, et al. Virologic analysis of non$\mathrm{B}$, non-C hepatocellular carcinoma in Japan: frequent involvement of hepatitis B virus. J Infect Dis 181: 1920-1928, 2000.

9) Shimada S, Aizawa R, Abe H, Suto S, Miyakawa Y, Aizawa Y. Analysis of risk factors for hepatocellular carcinoma that is negative for hepatitis B surface antigen (HBsAg). Intern Med 42: 389-393, 2003.

10) Wu J, Forbes JR, Chen HS, Cox DW. The LEC rat has a deletion in the copper transporting ATPase gene homologous to the Wilson disease gene. Nat Genet 7: 541-545, 1994. 
11) Mori M, Hattori A, Sawaki M, et al. The LEC rat: a model for human hepatitis, liver cancer, and much more. Am J Pathol 144: 200-204, 1994.

12) Sone $K$, Maeda $M$, Wakabayashi $K$, et al. Inhibition of hereditary hepatitis and liver tumor development in Long-Evans cinnamon rats by the copper-chelating agent trientine dihydrochloride. Hepatology 23: 764770, 1996.
13) Kato J, Kobune M, Kohgo Y, et al. Hepatic iron deprivation prevents spontaneous development of fulminant hepatitis and liver cancer in Long-Evans Cinnamon rats. J Clin Invest 98: 923-929, 1996.

14) Pfeil SA, Lynn DJ. Wilson's disease: copper unfettered. J Clin Gastroenterol 29: 22-31, 1999.

15) Fausto N. Mouse liver tumorigenesis: models, mechanisms, and relevance to human disease. Semin Liver Dis 19: 243-252, 1999. 